\title{
Accounting for Mandatory Payroll Deductions in Calculating AFDC Grants
}

In 1981 Congress adopted the Omnibus Budget Reconciliation Act of 1981 (OBRA), ${ }^{1}$ a series of budget-cutting measures aimed at reducing the growth of government spending. ${ }^{2}$ OBRA extensively amended the methods used in calculating eligibility and benefits under the Aid to Families with Dependent Children (AFDC) program. ${ }^{3}$ Among the changes adopted was the imposition of a seventy-five dollar limit on the amount of work-related expenses deductible from the income of working AFDC recipients before their grants are calculated." Prior to OBRA, all reasonable work expenses, ${ }^{6}$ such as the costs of transportation, ${ }^{6}$ uniforms, ${ }^{7}$ and child care ${ }^{8}$ were deductible, and the allowable deduction for such expenses had come to be known as the "work expense disregard."

The OBRA-imposed limit on the work expense disregard has

1 Omnibus Budget Reconciliation Act of 1981, Pub. L. No. 97-35, 95 Stat. 357.

2 See S. REp. No. 137, 97th Cong., lst Sess. 501-23 (1981) [hereinafter cited as Senate REPORT], reprinted in 1981 U.S. CODE CONG. \& AD. NEwS 396; infra text accompanying note 66.

s 42 U.S.C. $\$ \S 601-676$ (1976 \& Supp. V 1981). Congress adopted the AFDC program in order to promote the care of needy dependents in their own homes or in those of relatives and to assist those parents or relatives with whom they live to attain self-sufficiency. 42 U.S.C. $\$ 601$ (1976 \& Supp. V 1981). For a general discussion of the administration of the AFDC program, see infra note 16.

- 42 U.S.C. $\$ 602(a)(8)$ (Supp. V 1981). The work expense disregard is one of several amounts deducted from a recipient's resources in calculating her AFDC grant. In general, the purpose of the work expense disregard is to ensure that AFDC recipients have an incentive to work. See infra text accompanying notes 20-21.

- 42 U.S.C. $\$ 602(a)(7)$ (1976) (States shall "in determining need, take into consideration . . . any expenses reasonably attributable to the earning of any such income.").

- See, e.g., James v. O’Bannon, 715 F.2d 794, 799 (3d Cir. 1983) (transportation costs included in work expenses in Pennsylvania); Turner v. Prod, 707 F.2d 1109, 1112 (9th Cir. 1983) (same in California), cert. granted sub nom. Heckler v. Turner, 104 S. Ct. 1412 (1984).

7 See, e.g., James v. O'Bannon, 715 F.2d 794, 799 (3d Cir. 1983) (uniform costs included in work expenses in Pennsylvania); Turner v. Prod, 707 F.2d 1109, 1112 (9th Cir. 1983) (same in California), cert. granted sub nom. Heckler v. Turner, 104 S. Ct. 1412 (1984).

- OBRA also limited the child care expense deduction to $\$ 160$ per child per month. 42 U.S.C. $\$ 602(a)(8)(A)($ iii) (1976 \& Supp. V 1981).

- The term "work expense disregard" refers to a particular category of a recipient's resources-work expenses-that is excluded from consideration as income for purposes of determining eligibility for AFDC grants based on the amount of income available to the recipient and the amount of such a grant to which the recipient is entitled. James $v$. O’Bannon, 715 F.2d 794, 795 n.1 (3d Cir. 1983). 
given rise to a controversy over whether amounts mandatorily withheld from working recipients' payroll checks to pay federal and state taxes and Social Security contributions ${ }^{10}$ are to be included in calculating work expenses for purposes of applying the limit. The Department of Health and Human Services (HHS) has interpreted the work expense disregard limit to include mandatory payroll deductions. ${ }^{11}$ Nevertheless, the federal courts have disagreed on the issue, with some squarely rejecting the HHS interpretation as inconsistent with the Social Security Act. ${ }^{12}$ The Supreme Court has recently granted certiorari to consider the question. ${ }^{13}$

This comment assesses the opposing views on the treatment of mandatory payroll deductions in light of the legislative and administrative history of the statutory provisions for working AFDC recipients. ${ }^{14}$ The comment concludes that these provisions should be

10 This comment will use the term "mandatory payroll deductions" to refer to amounts so withheld.

${ }^{11}$ See, e.g., Petition for Certiorari at 4, Heckler v. Turner, 104 S. Ct. 1412 (1984), granting cert. to Turner v. Prod, 707 F.2d 1109 (9th Cir. 1983).

12 See, e.g., Turner v. Prod, 707 F.2d 1109 (9th Cir. 1983); cert. granted sub nom. Heckler v. Turner, 104 S. Ct. 1412 (1984); Clark v. Helms, No. 83-9-D, slip op. (D.N.H. Dec. 9, 1983); RAM v. Blum, 564 F. Supp. 634 (S.D.N.Y. 1983); Williamson v. Gibbs, 562 F. Supp. 687 (W.D. Wash. 1983), appeal docketed, No. 83-3725 (9th Cir. Apr. 7, 1983); Nishimoto v. Sunn, 561 F. Supp. 692 (D. Hawaii 1983), appeal docketed, No. 83-2214 (9th Cir. Apr. 4, 1983); RAM v. Blum, 533 F. Supp. 933 (S.D.N.Y. 1982). But see Dickenson v. Petit, No. 831676, slip op. (1st Cir. Feb. 23, 1984); Bell v. Massinga, 721 F.2d 131 (4th Cir. 1983); James v. O'Bannon, 715 F.2d 794 (3rd Cir. 1983); Gaston v. Schweiker, No. 82-1337, slip op. (N.D. Ohio Mar. 1, 1983).

${ }^{13}$ Heckler v. Turner, 104 S. Ct. 1412 (1984), granting cert. to Turner v. Prod, 707 F.2d 1109 (9th Cir. 1983).

1442 U.S.C. $\$ 602(a)$ (1976 \& Supp. V 1981) provides in relevant part:

A State plan for aid and services to needy families with children must ...

(7) except as may be otherwise provided in paragraph (8) . . of this title, provide that the State agency-

(A) shall, in determining need, take into consideration any other income and resources of any child or relative claiming aid to families with dependent children ...

(8)

(A) ... [I]n making the determination under paragraph (7), the State agency-

(ii) shall disregard from the earned income of any child or relative applying for or receiving aid to families with dependent children . . . the first $\$ 75$ of the total of such earned income for such month (or such lesser amount as the Secretary may prescribe in the case of an individual not engaged in fulltime employment or not employed throughout the month);

(iv) shall disregard from the earned income of any child or relative receiving aid to families with dependent children ... an amount equal to the 
construed to exclude mandatory payroll deductions from an AFDC recipient's income and thereby also exclude them from the recipient's work expense disregard in calculating her grant. This construction most effectively harmonizes the fundamental purposes of the AFDC program with those of OBRA.

\section{The AFDC Grant and the Work Incentive Disregards}

Under section 402(a)(7) of the Social Security Act, ${ }^{16}$ participating states $^{16}$ are required to base a recipient family's AFDC grant on its income and resources. ${ }^{17}$ This requirement makes a recipient family's AFDC grant vary inversely with its income, thereby creating a disincentive for a recipient to work. Yet one of the chief purposes of the AFDC program is to help parents or other custodial relatives of "needy dependent children . . . to attain or retain capability for the maximum self support and personal independence." ${ }^{18}$ Accordingly, a number of work incentive provisions have been built into the program. For example, states participating in the AFDC program are permitted to implement "workfare" programs, under which benefits may be reduced for, or denied to, recipients who refuse to seek employment. ${ }^{19}$ In addition

first $\$ 30$ of the total of such earned income not already disregarded under the preceding provisions of this paragraph plus one-third of the remainder thereof .... and

(B) provide that (with respect to any month) the State agency-

(ii) ... (II) in the case of the earned income of a person with respect to whom subparagraph (A)(iv) has been applied for four consecutive months, shall not apply the provisions of subparagraph (A)(iv) for so long as he continues to receive aid under the plan and shall not apply such provisions to any month thereafter until the expiration of an additional period of twelve consecutive months during which period he is not a recipient of such aid.

1342 U.S.C. \& 602(a)(7) (1976 \& Supp. V 1981).

18 The AFDC program is financed by both the states and the federal government on a matching fund basis. 42 U.S.C. $\$ 603$ (1976). Participating states must submit AFDC plans in conformity with the Act to the Secretary of the Department of Health and Human Services for approval. 42 U.S.C. $\$ 602$ (1976 \& Supp. V 1981). The program is administered primarily by the states, and, as the Supreme Court has repeatedly noted, the states are given broad discretion in determining the level of benefits. See Shea v. Vialpando, 416 U.S. 251, 253 (1974); Jefferson v. Hackney, 406 U.S. 535, 541 (1972); Dandridge v. Williams, 397 U.S. 471, 478 (1970); Rosado v.'Wyman, 397 U.S. 397, 408-09 (1970); King v. Smith, 392 U.S. 309, 318-19 (1968).

1742 U.S.C. $\$$ 602(a)(7)(A) (1976 \& Supp. V 1981).

1842 U.S.C. $\$ 601$ (1976 \& Supp. V 1981). This language was not altered by the 1981 OBRA amendments.

1042 U.S.C. \$ 609 (1976). Before OBRA, AFDC recipients could not be denied benefits if they refused to participate in the program. As of October 1, 1981, however, states can deny benefits to AFDC recipients who refuse, without good cause, to accept "workfare" employment. See 42 U.S.C. $\$ 609$ (c) (Supp. V 1981). For a discussion of the current workfare 
to the "workfare" option, Congress requires state AFDC programs to disregard certain types of income in calculating the amount of a recipient's grant. These work incentive disregards include the earned income disregard, which allows working recipients to deduct a flat percentage of their income during the first four months of employment, ${ }^{20}$ and the work expense disregard, which provides that the first seventy-five dollars of a recipient family's monthly income that is spent on work-related expenses shall be disregarded in calculating the amount of the AFDC grant. ${ }^{21}$

The Social Security Act thus requires states to perform a three-step calculation to determine the amount of a family's AFDC benefits. First, under section 402(a)(7), the amount of the family's income must be determined. ${ }^{22}$ Second, the family's adjusted income must be determined by subtracting the work-incentive disregards of section 402(a)(8) from the income determined in step one. ${ }^{23}$ Third, the AFDC benefits must be calculated by comparing the adjusted income found in step two to the standard of need established by the recipient's state of residence. ${ }^{24}$

The central question with respect to mandatory payroll deductions is whether they figure in step one of the benefit calculation by being excluded from income or whether they figure in step two by being included in the work expense disregard subtracted from income-that is, roughly speaking, whether they are to be deducted from gross or net income. Unfortunately, the language of the relevant provisions of the Social Security Act provides little guidance for resolving this issue.

From the time of the original enactment of the Social Security Act in 1935, state agencies have been obliged to consider any "income and resources" of AFDC recipients in calculating grants under that program. ${ }^{25}$ Yet the term "income" has never been defined in the Act. One might construe "income" to mean available, or net, income. ${ }^{26}$ This construction is supported by an HHS regula-

provision, see Comment, The 1981 AFDC Amendments: Rhetoric and Reality, 8 U. DAYToN L. REv. 81, 95-104 (1982).

${ }^{20}$ See 42 U.S.C. $\$ 602(a)(8)(A)(i v)$ (Supp. V 1981).

${ }^{21}$ Id. $\S 602(\mathrm{a})(8)(\mathrm{A})(\mathrm{ii})$ (Supp. V 1981).

${ }_{22}$ See id. § 602(a)(7)(A) (Supp. V 1981).

${ }^{23}$ See id. § 602(a)(8) (Supp. V 1981).

${ }^{24}$ See 45 C.F.R. § 233.20 (1983). The "standard of need" is "the amount deemed necessary by the State to maintain a hypothetical family at a subsistence level." Shea v. Vialpando, 416 U.S. 251, 253 (1974).

${ }^{25}$ Social Security Act Amendments of 1939, Pub. L. No. 76-379, § 401(b), 53 Stat. 1360, 1379 (codified at 42 U.S.C. § 602(a)(7) (Supp. V 1981)).

${ }^{28}$ See Turner v. Prod, 707 F.2d 1109, 1124 (9th Cir. 1983), cert. granted sub nom. 
tion directing that, in determining an AFDC recipient's need, only "[n]et income .... and resources available for current use shall be considered."27 This regulation embodies the "availability" principle of welfare law, under which income or resources in which the recipient has no legal interest or which are not available to her are not considered in determining eligibility for benefits. ${ }^{28}$

A second construction of the term "income" is also plausible. Since 1968, section 402(a)(7), which provides that a recipient's income must be considered in determining whether to award benefits to her, has been prefaced by the language "except as may be otherwise provided in paragraph 8." "29 Paragraph eight provides that the work expense disregard be taken from "earned income."30 An HHS regulation defines "earned income" as "the total amount [of income], irrespective of personal expenses, such as income-tax deductions." ${ }^{31}$ HHS's current position is that the availability principle of section 402(a)(7) is subject to the "earned income" provision of 402(a)(8), and HHS interprets "earned income" as referring to gross income. ${ }^{32}$ This argument has convinced some courts to abandon the availability principle in adjudicating disputes over the interpretation of section $402(a)(8) .^{33}$

The practical significance of the choice between these two constructions of "income" is apparent when one considers their respective effects on the order of exclusionary calculations under sections 402(a)(7) and (8). Under both views, mandatory payroll deductions are disregarded in calculating the income of AFDC recipients, but under the net or available income construction, mandatory payroll deductions are disregarded before-and separately from-work expenses, while under the gross income construction, mandatory payroll deductions are disregarded as work expenses. The latter construction has the effect of reducing the size

Heckler v. Turner, 104 S. Ct. 1412 (1984).

${ }^{27} 45$ C.F.R. $\$ 233.20$ (a)(3)(ii)(D) (1983). "[I]ncome and resources are considered available both when actually available and when the applicant or recipient has a legal interest in a liquidated sum and has the legal ability to make such sum available for support and maintenance." Id.

${ }^{23}$ See, e.g., Van Lare v. Hurley, 421 U.S. 338 (1975); Lewis v. Martin, 397 U.S. 552 (1970); King v. Smith, 392 U.S. 309 (1968); infra note 90. The applicability of the availability principle to mandatory payroll deductions is discussed infra text accompanying notes 88-99.

29 42 U.S.C. $\$ 602(a)(7)$ (A) (1976 \& Supp. V 1981).

${ }^{30} I d$. § 602(a)(8)(A)(ii) (1976 \& Supp. V 1981).

3145 C.F.R. $\$ 233.20(a)(6)(i v)$ (1983).

s2 See Petition for Certiorari at 10, Heckler v. Turner, 104 S. Ct. 1412 (1984).

ss See, e.g., Bell v. Massinga, 721 F.2d 131 (4th Cir. 1983); James v. O'Bannon, 715 F.2d 794 (3d Cir. 1983). 
of grant amounts for a working AFDC recipient where the total of her other work expenses and payroll deductions exceeds seventyfive dollars since including mandatory payroll deductions in the seventy-five dollars work expense allowance results in denying the disregard to work expenses actually incurred on items such as transportation and uniforms. ${ }^{34}$

\section{Legislative and Administrative History}

The legislative and administrative history of the work expense disregard divides naturally into three stages: from 1935, when the AFDC program was enacted, ${ }^{35}$ to 1962 , when the work expense disregard was first added to the statute; ${ }^{36}$ from 1962 to 1981 , the years between the enactment of the work expense disregard and the adoption of the OBRA amendments; ${ }^{37}$ and since 1981, the year in which Congress imposed the limitation on the work expense disregard.

\section{A. 1935 to 1962}

The Social Security Act of 1935 did not expressly require that states consider a family's income when calculating its AFDC

st The effect of allowing mandatory payroll deductions to figure in the calculation of available income rather than in the calculation of the work expense disregard may be illustrated by the following example discussed in Turner v. Prod, 707 F.2d 1109, 1112 (9th Cir. 1983), cert. granted sub nom. Heckler v. Turner, $104 \mathrm{~S}$. Ct. 1412 (1984). In 1982, a California mother with three children who earned the minimum wage ( $\$ 3.25$ an hour) would have made $\$ 576.20$ per month and had $\$ 59.52$ withheld from her paycheck for federal and state income taxes, FICA, and state disability insurance. If the grant were calculated from net income, she would still have $\$ 75$ available to cover her work-related expenses for transportation, uniforms, union dues, etc., leaving her with $\$ 441$ after deductions and disregards. Assuming a state benefit level of $\$ 601$, the $\$ 441$ would be subtracted from that amount, giving her a monthly AFDC grant of $\$ 160$. If the calculation is made from gross income, the mandatory payroll deductions would make up $80 \%$ of her work-related expense allowance of $\$ 75$. She would be left with an amount after disregards of $\$ 501$, which, when subtracted from the $\$ 601$ benefit level, leaves $\$ 100$ in grant money, $\$ 60$ less than if the grant were calculated from net income. The $\$ 60$ grant reduction decreases the family's monthly AFDC grant by approximately $38 \%$ and reduces the amount of money available each month by approximately $10 \%$. HHS has estimated that calculating AFDC grants by treating mandatory payroll deductions as included in the work expense disregard would increase grants to working AFDC recipients by approximately $\$ 57$ million annually. See Petition for Certiorari at 10 n.4, Heckler v. Turner, 104 S. Ct. 1412 (1984).

ss Social Security Act of 1985, Pub. L. No. 74-271, $\S \$ 401-06,49$ Stat. 620, $627-29$ (codified as amended at 42 U.S.C. $\S \S 601-76$ (1976 \& Supp. V 1981)).

${ }^{38}$ Public Welfare Amendments of 1962, Pub. L. No. 87-543, § 106(b), 76 Stat. 172, 188 (codified as amended at 42 U.S.C. § 602 (a)(8) (1976 \& Supp. V 1981)).

s7 Omnibus Budget Reconciliation Act of 1981, Pub. L. No. 97-35, §2301, 95 Stat. 357, 843-44 (codified at 42 U.S.C. $\$ 602(a)(8)$ (Supp. V 1981)). 
grant. ${ }^{38}$ Therefore, states were able to disburse AFDC grants without regard to a recipient's outside income. In 1939 Congress rectified this omission by adding what is now section $402(\mathrm{a})(7)$ to the Act. ${ }^{3 \theta}$

The Congress that enacted section 402(a)(7) did not indicate whether it intended to exclude mandatory payroll deductions from the income and resources of AFDC recipients to be "take[n] into consideration" under section 402(a)(7). This omission is not surprising, for in 1939 mandatory payroll deductions were withheld only for Social Security contributions, ${ }^{40}$ and not for federal ${ }^{41}$ or state $^{42}$ taxes. Yet Social Security officials and individual congressmen expressed concern that state agencies not include as "income" money not actually available to AFDC recipients. ${ }^{43}$ In 1940 , the Social Security Board ${ }^{44}$ issued a policy statement interpreting section 402(a)(7) as requiring consideration only of income that "actually exists [and is] . . . available to the applicant."4s The policy statement defined "available" as meaning "actually on hand or

38 Social Security Act of 1935, Pub. L. No. 74-271, § 402, 49 Stat. 620, 627-29.

30 Social Security Amendments of 1939, Pub. L. No. 76-379, $\S 402(\mathrm{~b}), 53$ Stat. 1360, 1379-80 ("[T]he State agency shall, in determining need, take into consideration any other income and resources of any child claiming aid to dependent children . . . .") (amending Social Security Act of 1935, Pub. L. No. 74-271, $\S 402$ ), 49 Stat. 620, 627-28 (codified at 42 U.S.C. § 602(a)(7) (1976)) (amended 1981).

10 Mandatory payroll deductions of FICA (social security) taxes began in 1935 with the passage of the Social Security Act of 1935, Pub. L. No. 74-271, § 802(a), 49 Stat. 620, 636.

1 The practice of withholding amounts from paychecks for federal income tax purposes was first required in 1943. See Current Tax Payment Act of 1943, Pub. L. No. 78-68, ch. 120, 57 Stat. 126.

12 See RAM v. Blum, 564 F. Supp. 634, 639 n.10 (S.D.N.Y. 1983).

4s See, e.g., Hearings Relative to the Social Security Act Amendments of 1939 Before the House Committee on Ways and Means, 76th Cong., 1st Sess. 2254 (1939) ("[We] do require that the States take into account, in determining need, any contributions that relatives actually make...." (emphasis added)) (statement of Arthur Altmeyer, Chairman, Social Security Board); cf. 84 Cong. REc. 6851 (1939) (remarks of Rep. Poage) (expressing concern that the new income provision not be used to "deny some needy . . . person the aid to which he is entitled.").

"As the Court noted in RAM v. Blum, 564 F. Supp. 634, 639 n.11 (S.D.N.Y. 1983), the AFDC program has been administered by four federal agencies during its 48 -year history. From 1935 until 1946 it was managed by the Social Security Board. The Federal Security Agency administered the program from 1946 until 1953. See Reorganization Plan No. 2 of 1946, 60 Stat. 1095. In 1953 the newly created Department of Health, Education and Welfare took over the program's administration. See Reorganization Plan No. 1 of 1953, 67 Stat. 631. In 1979 the Department of Health, Education and Welfare was replaced by the Department of Health and Human Services. See Department of Education Organization Act, Pub. L. No. $96-88, \S 509,93$ Stat. 668,695 (1979).

15 RAM v. Blum, 564 F. Supp. 634, 639 n.14 (S.D.N.Y. 1983) (quoting Social Security Board, Policy Statement 2 (Dec. 2, 1940)). 
ready for use when ... needed."4s Two years later, the policy statement was incorporated into the Board's Guide to Public Assistance Administration. ${ }^{47}$

Although the 1939 amendments did not require disregard of work expenses, the states were permitted to disregard them if they chose. ${ }^{48}$. The 1957 edition of the Handbook of Public Assistance issued by the Department of Health, Education and Welfare (HEW) included a list of items that state agencies might disregard, including amounts paid for food, clothing, and personal incidentals but not mandatory payroll deductions. ${ }^{49}$ Given the monetary significance of mandatory payroll deductions in $1957,,^{50}$ it is unlikely that HEW's failure to categorize them as work expenses was inadvertent. Rather, inclusion of mandatory payroll deductions as a work expense was unnecessary, since the administrative practice before 1962 had been to use net income as the basis for calculating AFDC grants. ${ }^{51}$ A $1961 \mathrm{HEW}$ report noted that forty-eight states published lists of items considered "deductible employment costs." ${ }^{12}$ Although none of these lists included taxes, ${ }^{53}$ it was re-

18 Id.

17 RAM v. Blum, 564 F. Supp. 634, 640 n.15 (S.D.N.Y. 1983) ("[I]ncome when considered . . . should be real and not fictitious . . . [and] should be actually on hand or ready for use when it is needed.") (quoting Social Security Board, Guide to Public Assistance Ad. MINISTRATION § 202, at 2 (1942)).

48 See HEW, Handbook of Public Assistance Administration (pt. 4), § 3140 (1957).

19 A State public assistance agency may establish a reasonable minimum money amount to represent the combined additional cost of three items-food, clothing, and personal incidentals-for all employed persons. The State plan may provide that other items of work expense will be allowed when there is a determination that such expenses do, in fact, exist in the individual case.

Id., quoted in RAM v. Blum, 564 F. Supp. 634, 643 (S.D.N.Y. 1983).

so By 1957 employers were required to withhold money from employee paychecks for federal income taxes, see supra note 41 . Since the advent of general tax withholding, mandatory payroll deductions are frequently nearly as great as the total of all the expenses enumerated in the HEW list:

For most families with an employed member, mandatory payroll deductions would apparently entail more money than any item listed in section 3140 [HEW, supra note 48, at $\S 3140]$. Indeed, the figures available to the Court indicate that mandatory payroll deductions may often be nearly equal in amount to the total of all section 3140 employment expenses combined. It is unimaginable that so significant an item would have been left out of section 3140 if, as defendants contend, mandatory payroll deductions were being treated as "employment expenses."

RAM v. Blum, 564 F. Supp. 634, 643 (S.D.N.Y. 1983).

s2 See infra note 54 and accompanying text.

62 Social Security Administration Bureau of Public Assistance, State Methods for Determining Need in the Aid to Dependent Chimdren Program 25 (HEW Public Assistance Report No. 43, 1961).

ss Id. The items listed included transportation (38 states), special tools and equipment (23 states), uniforms and/or other special clothing (22 states), cost of child care (21 states), 
ported that the states almost uniformly calculated the AFDC grant from "take-home pay," or net income. ${ }^{54}$

\section{B. 1962 to 1981}

In 1962, Congress, for the purpose of creating a work incentive ${ }^{55}$ made mandatory the "widespread but then optional practice"s8 of excluding work expenses from the calculation of AFDC grants. $^{57}$ The legislative history of the 1962 amendment made no mention of mandatory payroll deductions as work expenses. ${ }^{88}$ The Handbook of Public Assistance, amended by HEW in 1963, again omitted mandatory payroll deductions from its enumeration of work expenses..$^{59}$

In 1974 the Supreme Court, in Shea $v$. Vialpando ${ }^{80}$ held that under section 402(a)(7), which at that time required that "all expenses reasonably attributable" to employment be disregarded from the recipient's income in calculating the recipient's AFDC grant, $^{61}$ a state agency could not adopt a standardized maximum allowance for work expenses. For most state programs that, like

lunches (15 states), and collection for employee benefits (7 states).

st Id. According to the Report, "The term 'gross income,' as used by the States in these policies, refers to 'take-home pay' after payroll deductions for union dues, income tax, retirement, and other such items have been made. 'Net income' refers to amounts available after other employment costs have been recognised." Id.

Bs As HEW Secretary Ribicoff testified during the Hearings on the 1962 amendment:

What we are trying to do ... is do everything we can to encourage the States. By having this provision, the State will take into account these expenses so people will get jobs. I believe that the State should give them an allowance for those items that are necessary for them to get a job.

Hearings on the Public Assistance Act of 1962 Before the Senate Committee on Finance, 87th Cong., 2d Sess. 152 (1962); see S. REP. No. 1589, 87th Cong., 2d Sess. 17-18 (1962), reprinted in 1962 U.S. Code Cong. \& AD. News 1943, 1960 ("[I]f these work expenses are not considered in determining need, they have the effect of providing a disincentive to working . . . . "); H.R. REP. No. 1414, 87th Cong., 2d Sess. 23 (1962).

se Shea v. Vialpando, 416 U.S. 251, 260 (1974).

s7 "[T] income and resources of any child or relative claiming aid to families with dependent children, as well as any expenses reasonably attributable to the earning of any such income ... " Public Welfare Amendments of 1962, Pub. L. No. 87-543, § 106, 76 Stat. 172, 188 (1962) (codified at 42 U.S.C. $\$ 602(a)(7)(1976)$ ).

ss See Turner v. Prod, 707 F.2d 1109, 1120 (9th Cir. 1983), cert. granted sub nom. Heckler v. Turner, 104 S. Ct. 1412 (1984).

s2 The 1963 Handbook retained the listing of "food, clothing and personal incidentals" from the 1957 Handbook, see HEW, supra note 48, at $\$ 3140$, but added a more detailed list of items including uniforms, transportation, collections for employee benefits, tools, licenses, union or other dues, education, publications, child care, and protective clothing. HEW, Handbook of Public Assistance Administration (pt. 4), § 3140 (1963).

416 U.S. 251 (1974).

- See id. at 254. 
the Colorado program rejected in Shea, ${ }^{62}$ had standardized allowances, the imposition of the standard allowance had had no effect on mandatory payroll deductions, which were separately deductible. ${ }^{63}$ The Court in Shea did not explicitly decide whether mandatory payroll deductions were to be included in the work expense disregard. The Court simply required the states to disregard fully "any expenses reasonably attributable to the earning of income." S4 Such expenses included both mandatory payroll deductions and work expenses. It was only after Shea that state agencies began to list mandatory payroll deductions as "work expenses" on the forms used in calculating AFDC grants. ${ }^{65}$ This may have been due to administrative convenience, for under the Shea holding it made no practical difference how mandatory payroll deductions were classified. Whether classified as unavailable and therefore not income, or as work expenses, and therefore deductible, mandatory payroll deductions would be excluded from the income base used for calculating AFDC grants.

\section{1981: The OBRA Amendments}

In 1981 Congress enacted the OBRA budget cuts in order to "wage an effective battle against [the] high inflation and unemployment which have plagued the national economy for many years." reveals that Congress had three specific reasons for imposing the seventy-five dollar limit on the work expense disregard: to reduce variation among the states in the amount allowed for the work expense disregard; ${ }^{67}$ to prevent abuse by AFDC recipients who might

${ }^{62}$ See id. at 255. The Colorado work expense regulation is found at 4 Colorado Drvision of Public Welfare, Staff Manual $\$ 4313.13$ (1970).

${ }^{63}$ In February 1972, fifteen states used a standardized deduction for work expenses other than child care. Twelve of these fifteen states required that mandatory payroll deductions be itemized separately from and in addition to the state's standard work expense disregard. RAM v. Blum, 564 F. Supp 634, 644 (S.D.N.Y. 1983).

B4 416 U.S. at 254.

${ }^{65}$ RAM v. Blum, 564 F. Supp. 634, 644 (S.D.N.Y. 1983); see James v. O' Bannon, 715 F.2d 794, 807 (3d Cir. 1983) (noting that withheld taxes and work expenses were not viewed as "conceptually distinct").

so Senate Report supra note 2, at 3, reprinted in 1981 U.S. Code Cong. \& Ad. NewS $396,398$.

${ }^{87}$ States are free to define which expenses they consider "reasonably attributable" and State policies vary. Some states provide no disregard for child care expenses, paying for care instead through the Title XX social services program. Some states put limits on the amounts they will allow for child care. Many States have limits on amounts they will allow for such items as lunches, transportation, or uniforms.

Id. at 501, reprinted in 1981 U.S. CoDE CoNG. \& AD. News 396, 767. 
otherwise report excessive work expenses; ${ }^{68}$ and to reduce administrativè complexity and error by providing for a standardized deduction rather than itemized work expenses. ${ }^{69}$

Nowhere in the legislative history of OBRA is there a specific discussion of the proper treatment of mandatory payroll deductions. OBRA itself makes no mention of payroll deductions in particular, though it does move the work expense disregard from section 402(a)(7), the section providing for the calculation of available income ${ }^{70}$ to section $402(\mathrm{a})(8)$, the section which now provides for the deduction of earned income, child care, and work expense disregards from the income computed under section 402(a)(7). ${ }^{71}$ Nonetheless, HHS has taken the position that the work expense disregard is now to be taken from gross income, and therefore includes mandatory payroll deductions. ${ }^{72}$

\section{ANALYSIS}

As the Supreme Court has observed, the AFDC program is an area in which Congress has at times "voiced its wishes in muted strains and left it to the courts to discern the theme in the cacaphony of political understanding."73 Such is the case with the application of the seventy-five dollar limit on work-related expenses to mandatory payroll deductions. The issue cannot be resolved by resort merely to the language of sections $402(\mathrm{a})(7)$ and (8) of the Social Security Act. Under such circumstances, courts are frequently inclined to defer to administrative interpretation of the statute at issue. ${ }^{74}$ Yet, while an agency's interpretation with a "reasonable basis in law" is entitled to judicial deference, ${ }^{75}$ a court may not properly defer to an administrative interpretation that is plainly erroneous or inconsistent with the statute or regulation being interpreted..$^{76}$ Under this standard, HHS's construction of the

is See id.; 127 Cong. REc. S1901-02 (daily ed. Mar. 6, 1981) (statement of Sen. Inouye).

69 See Senate Report, supra note 2, at 501-02, reprinted in 1981 U.S. Code Cong. \& AD. News 396, 768.

${ }^{70}$ See supra text accompanying note 22.

${ }^{71}$ See supra text accompanying note 23 .

${ }^{2}$ Petition for Certiorari, Heckler v. Turner, 104 S. Ct. 1412 (1984).

73 Rosado v. Wyman, 397 U.S. 397,412 (1970).

7 See Monaghan, Marbury and the Administrative State, 83 CoLum. L. REv. 1, 30 \& n.176 (1983).

73 NLRB v. Hearst Publications, Inc., 322 U.S. 111, 131 (1944); see United States v. Rutherford, 442 U.S. 544, 553-54 (1979).

${ }^{76}$ See Shea v. Vialpando, 416 U.S. 251, 262 n.11 (1974) (rejecting HEW's construction of $\S 402(a)(7)$ ); see also Townsend v. Swank, 404 U.S. 282, 286 (1971) (rejecting HEW's construction of $\S 402(a)(10)$ as inconsistent with the Act); Pratt \& Whitney Aircraft v. Sec- 
work expense disregard provision as including mandatory payroll deductions should be rejected. The agency interpretation rests on a regulation that has been rendered obsolete by the OBRA amendment of section 402(a)(8), and it is inconsistent with the fundamental availability principle of the Social Security Act, the work incentive policy underlying the AFDC program, and longstanding administrative practice. The alternative-to subtract mandatory payroll deductions from the income calculated under section 402 (a)(7) because they represent income that is unavailable to the recipient ${ }^{77}$-is more consistent with the policies of the Social Security Act and the purposes of the OBRA amendment of the work expense disregard.

\section{A. Obsolete Administrative Definition of "Earned Income"}

HHS's argument that mandatory payroll deductions should be included within the seventy-five dollar work expense disregard rests upon an HHS regulation defining the term "earned income" in section $402(a)(8)$ as gross income. ${ }^{88}$ This regulation has, however, been rendered obsolete by the OBRA amendment of section 402(a)(8).

The regulation defining "earned income" was promulgated in 1969.79 As the regulation was initially proposed in 1968, "earned income" was defined as net income for the purpose of the earned income disregard..$^{80}$ After receiving comments, HEW changed the regulation so that the earned income disregard would be calculated from gross income. ${ }^{81}$ Because the earned income disregard is composed partly of a percentage of earned income, ${ }^{82}$ using gross income as the base-line had the effect of increasing the amount of the disregard and therefore of the AFDC grant. The change in definition of "earned income" to one calculated from gross income appears to have been motivated by a recognition of the congressional intent "to maximize the employment incentive to recipient fami-

retary of Labor, 649 F.2d 96, 103 (2d Cir. 1981) (interpretation must be consistent with enabling act under which it was promulgated); Miller v. Bond, 641 F.2d 997, 1002 (D.C. Cir. 1981); Foulkes v. Commissioner, 638 F.2d 1105, 1110 n.17 (7th Cir. 1981); Ruangswang v. INS, 591 F.2d 39, 43 (9th Cir. 1978).

${ }^{77}$ See supra notes 27-28 and accompanying text.

z8 See 45 C.F.R. \& 233.20(a)(6)(iv) (1983); supra text accompanying note 32.

7945 C.F.R. \& 233.20(a)(6)(iv) (1983); see supra text accompanying note 31 .

so See 33 Fed. Reg. 10230 (1968) (proposed July 17, 1968).

s1 See 34 Fed. Reg. 1394 (1969).

${ }^{82}$ See 42 U.S.C. $\S 602(a)(8)(A)$ (iv) (1976 \& Supp. V 1981). For a brief discussion of the earned income disregard, see supra text accompanying note 20. 
lies." "83 The Second Circuit relied upon this explanation to uphold the HEW definition of "earned income" in 1971..$^{84}$

The principal rationale for the HHS definition of "earned income" as gross income-that it would maximize work incentives to AFDC recipients by increasing the size of their earned income disregard-did not survive the OBRA amendment of section 402(a)(8), which reordered the procedure for calculating grants so that the earned income disregard is now calculated as a percentage of the recipient's income after the child care and work expense disregards have been subtracted. ${ }^{85}$ The provision that the earned income disregard be calculated on an amount less than gross income defeats the original purpose of defining "earned income" as gross income: increasing the amount of earned income disregard so as to increase the recipient's incentive to work. Application of this regulation to the work expense disregard is at odds with the original purpose of both the regulation and the work expense disregard itself for the same reason: ${ }^{8}$ it would vitiate the work incentive effect of the disregard by reducing its amount. ${ }^{87}$

\section{B. Inconsistency of the HHS Interpretation of Section 402(a)(8) with the Social Security Act}

1. The Availability Principle. The applicability to section 402(a)(7) of the availability principle-that income and resources not actually available for current use to welfare recipients should not be considered in calculating benefits ${ }^{88}$ - has long-standing administrative ${ }^{89}$ and judicial ${ }^{90}$ recognition.

ss RAM v. Blum, 564 F. Supp. 634, 648 n.32 (S.D.N.Y. 1983).

st See Connecticut State Dept. of Welfare v. HEW, 448 F.2d 209, 215 (2d Cir. 1971) ("The Secretary's formula ... provides recipients with greater incentives for engaging in gainful employment.").

ss See 42 U.S.C. \& $602(a)(8)$ (A)(iv) (1976 \& Supp. V 1981). OBRA also limited the earned income disregard to the recipient's first four months of continuous employment. Id. OBRA's limitation of the earned income disregard was motivated by a perception that it was an ineffective work incentive. See SENATE REPORT, supra note 2, at 502, reprinted in 1981 U.S. Code Cong. \& AD. News 396, 738. For a general discussion of the effect of OBRA on the earned income disregard, see Comment, supra note 19, at 85-92.

so See supra note 55 and accompanying text.

37 See supra text accompanying note 34; infra text accompanying notes 106-13.

se See 45 C.F.R. $\$ 233.20$ (a)(3)(ii)(D) (1982); supra notes 25-28, 44-47 and accompanying text.

so See supra text accompanying notes 40-47.

- See, e.g., Van Lare v. Hurley, 421 U.S. 338 (1975) (invalidating a state statute that created a presumption that a nonpaying lodger in the home of an AFDC recipient contributed to the support of the household); Lewis v. Martin, 397 U.S. 552 (1970) (invalidating a state regulation requiring that the income of a stepfather who had not adopted the recipient 
In National Welfare Rights Organization $v$. Mathews, ${ }^{91}$ the District of Columbia Circuit applied the availability principle to hold that only the recipient's equity in an encumbered asset, and not the asset's market value, could be considered a resource under section 402(a)(7). Considering gross, rather than net, income as the basis for calculating an AFDC recipient's benefits is like considering the full market value of an encumbered asset as a resource of its owner. An AFDC recipient may earn her gross income, just as she may hold legal title to an encumbered asset. However, amounts withheld from earnings for federal or state taxes are no more available to meet the immediate needs of the wage-earner than is the full market value of a property owner's encumbered asset. ${ }^{92}$

To cast aside the availability principle in calculating the work expense disregard is inconsistent with longstanding agency practice that has received overwhelming judicial approval, ${ }^{93}$ and this fact alone might be reason enough to reject HHS's position on the issue.94 But the inconsistency is particularly troubling in light of Congress's amendments to section 402(a)(7) in 1962, 1967, and 1968 , in the course of which Congress made no attempt to reject either the availability principle or the administrative practice of fully disregarding mandatory payroll deductions. ${ }^{95}$ Indeed, $M a-$ thews is cited with approval in the legislative history of OBRA it-

mother's children be included in the income of the AFDC family); King v. Smith, 392 U.S. 309 (1968) (invalidating a state "substitute father" rule denying AFDC benefits to the children of unmarried mothers cohabitating with men).

21533 F.2d 637 (D.C. Cir. 1976).

82 One district court case may lend support to an argument that amounts withheld from paychecks for taxes are available to AFDC recipients. In Powell v. Austin, 427 F. Supp. 749 (E.D. Va. 1977), the court held that an AFDC recipient's garnished wages could be treated as "income" in the calculation of benefits. Id. at 751. The court ruled that garnished wages are available because "they provide actual, not assumed, benefits to the recipients, in the form of extinguishing part of an outstanding debt." Id. Withheld taxes might be analogized to garnished wages since they also extinguish an outstanding liability.

The holding in Powell, however, is fundamentally at odds with the availability principle and should therefore not be extended. Garnished wages are not "actually on hand" to meet the recipient's immediate needs. See RAM v. Blum, 564 F. Supp. 634, 639 n.14 (S.D.N.Y. 1983) (quoting Social SECURITY BoARD, supra note 47, at 27). Even if Powell is correctly decided, mandatory payroll deductions are distinguishable from garnished wages. A personal debt is one voluntarily incurred in order to obtain benefits chosen by the debtor. The wages burdened by the debt, unlike the withheld taxes, were once available to the wage-earner.

ss See supra note 90 .

24 See Morton v. Ruiz, 415 U.S. 199, 237 (1974) (deference afforded to an agency interpretation depends on its consistency with previous agency interpretations); cf. EEOC v. Associated Dry Goods Corp., 449 U.S. 590, 600 n.17 (1981) ("[A] contemporaneous construction deserves special deference when it has remained consistent over a long period of time.").

ss See supra notes 88-90 and accompanying text. 
self, ${ }^{96}$ thereby giving the availability principle and the practice of fully disregarding mandatory payroll deductions tacit congressional approval. ${ }^{97}$ In this sense, the argument that gross income is the base-line for the work expense disregard is inconsistent with the Social Security Act.

Courts rejecting the application of the availability principle to mandatory payroll deductions distinguish availability cases on the ground that they merely stand for the proposition that "the states cannot presume or assume the existence of resources or income sources." This distinction is meritless. From the perspective of the availability principle, which considers what is "on hand or ready for use when it is needed," ence between available income sources and the available income itself.

2. Work Incentives. In enacting OBRA, Congress sought to reduce welfare spending. ${ }^{100}$ This goal was achieved in part by placing limitations on the earned income, ${ }^{101}$ child expense, ${ }^{102}$ and work expense disregards. ${ }^{103}$ While these changes may embody a trend toward decreased reliance on the work incentive approach to welfare policy, they do not signify abandonment of that approach. OBRA's retention of the section 402(a)(8) disregards attests to Congress's enduring concern that welfare recipients be provided with work incentives. The fundamental purpose of assisting needy families to attain self-sufficiency remains embedded in the AFDC statute. ${ }^{104}$

Without the section 402(a)(8) disregards, AFDC recipients would lack any monetary incentive to work. The amount that the

os "States were formerly allowed to value resources on the basis of fair market value. However, as a result of a circuit court decision in NWRO v. Mathews, the regulations were changed to require that all resources be valued on the basis of fair market value less encumbrances, or equity value."

Senate Report, supra note 2, at 503, reprinted in 1981 U.S. Code Cong \& Ad. News 396, 769.

${ }^{97}$ See Turner v. Prod, 707 F.2d 1109, 1116 (9th Cir. 1983), cert. granted sub nom. Heckler v. Turner, 104 S. Ct. 1412 (1984).

s Dickenson v. Petit, 536 F. Supp. 1100, 1116 n.13 (D. Me. 1982), aff'd, No. 38-1696, slip op. (1st Cir. Feb. 23, 1984). See James v. O'Bannon, 557 F. Supp. 631, 640 (E.D. Pa. 1982), aff'd, 715 F.2d 794 (3d Cir. 1983).

? See RAM v. Blum, 564 F. Supp. 634, 639 n.14 (S.D.N.Y. 1983) (quoting Social SeCURITY BOARD, supra note 47 , at 2).

100 See Senate Report, supra note 2, at 3, reprinted in 1981 U.S. Code Cong. \& AD. News 396, 398; supra note 66 and accompanying text.

101 See supra note 85 and accompanying text.

102 See supra note 8 and accompanying text.

${ }^{103}$ See supra notes 3-8 and accompanying text.

${ }^{104}$ See 42 U.S.C. $\$ 601$ (1976). 
welfare check is reduced for every dollar earned is equivalent to a tax on earnings. ${ }^{105}$ Thus, if an AFDC recipient earns $\$ 1000$ and her benefits are reduced by $\$ 300$, it is as if a $30 \%$ tax had been imposed on her earnings. As the effective tax rate increases to $100 \%$, the recipient's incentive to work is reduced.

Under the current system of welfare disregards, the effective "welfare tax rate"106 of a working AFDC recipient, after the four months during which the earned income disregard operates have elapsed, ${ }^{107}$ is at least $100 \%$, even if mandatory payroll deductions are excluded from her income separately from work expenses. Excluding mandatory deductions and disregarding the work and child-care expenses only compensates the recipient for expenses she would not incur if she did not work. Even if these disregards did fully compensate the recipient for her work and child-care expenses, her welfare benefits would be reduced one dollar for every dollar of earned income, the equivalent of a tax rate of $100 \% .^{108}$ If the recipient's actual work expenses exceed the statutory limitation, her welfare tax rate will exceed $100 \%$. Unless her salary so far exceeds the state standard of need that she is ineligible for and is no longer in actual need of welfare benefits, she is actually penalized for working. Including mandatory payroll deductions within the $\$ 75$ work expense disregard can only exacerbate this penalty and its work-disincentive effect.

The effect of including mandatory payroll deductions in the work expense disregard is readily demonstrable. In California, for example, the actual work expenses of AFDC recipients average $\$ 80$ per month, ${ }^{109} \$ 5$ more than the statutory limit. The average AFDC recipient is therefore already subject to a slight work disincentive after her eligibility for the earned income disregard has expired. In California, the average working AFDC recipient has $\$ 83$ withheld

${ }^{105}$ For a discussion of the disincentive effect of current welfare programs, see M. ANDERSON, WeLFARE 87-132 (1978).

${ }^{108}$ See id. at 136-37.

${ }^{107} 42$ U.S.C. $\$ 602(a)(8)(A)(i v)$ (1976 \& Supp. V 1981).

${ }^{108}$ This example assumes that the total wages of the unemployed AFDC recipient is less than the amount designated by the state as the "standard of need." Of course, if a recipient's total wages, reduced by work and child-care expenses, were greater than the state's standard of need, she would have gained by working. But then she would qualify for no AFDC benefits at all.

${ }^{109}$ Turner v. Woods, 559 F. Supp. 603, 614 (N.D. Cal. 1982). In Woods, the district court based its findings on the state agency's 1980 statistics. Id. at 614 (quoting CaLIForNia State Department of Social Services, AFDC Soclal and Economic Characteristics for Familtes Receiving Am During July 1980 table 18 (1982) (Program Series Information Report 1982-01)). 
from her monthly wages for state and federal taxes. ${ }^{110}$ If these were included under the work expense disregard along with her actual work expenses, she would receive a $\$ 75$ credit to cover $\$ 163$ in expenses, and her family would be $\$ 88$ poorer than if she had decided not to work. The inclusion of mandatory payroll deductions in the work expense disregard would actually fine California recipients for working. ${ }^{111}$ In other states, where work expenses or mandatory payroll deductions are lower, ${ }^{112}$ the disincentive effect is somewhat less marked, ${ }^{113}$ but in all states the inclusion of mandatory payroll deductions in the work expense disregard severely limits its work incentive effect. ${ }^{114}$

As the Ninth Circuit noted, "the choice is between working and not working. If the disincentive provided is strong enough, there is no reason to believe that AFDC recipients will work in order to pay handsomely for the privilege."115 Although it is difficult to pinpoint exactly what welfare tax rate will prevent welfare recipients from working, ${ }^{116}$ treating mandatory payroll deductions as work expenses so as to create a work disincentive is inconsistent both with the AFDC program's purpose of encouraging recipients

${ }_{110}$ Turner v. Woods, 559 F. Supp. 603, 614 (N.D. Cal. 1982).

111 Turner v. Prod, 707 F.2d at 1109, 1123 (9th Cir. 1983), cert. granted sub nom. Heckler v. Turner, $104 \mathrm{~S}$. Ct. 1412 (1984). Because of the high cost of work-related expenses in California, some working recipients would be penalized for working even if mandatory payroll deductions were disregarded before work expenses. See, e.g., supra text accompanying note 109. The disincentive to work is much less, however, than it would be if mandatory payroll deductions were included in the work expense disregard.

112 Turner v. Prod. 707 F.2d 1109, 1123 (9th Cir. 1983), cert. granted sub nom. Heckler v. Turner, 104 S. Ct. 1412 (1984).

113 According to a recent study by the University of Chicago's Center for the Study of Social Policy, under current HHS calculations, AFDC recipients in twelve states, including California, lose money if they work. Those in another nine states earn less than ten dollars in extra income for a full month of work. The disincentive effect of the current AFDC program cannot be attributed solely to the inclusion of mandatory payroll deductions in the work expense disregard; the limitation on the earned income disregard has also contributed to the reduction in work incentives. See United States Commission on Crvil Rights, A Growing Crisis: Disadvantaged Women and their Children 28-29 (1983).

114 See, e.g., RAM v. Blum, 564 F. Supp. 634, 647 (S.D.N.Y. 1983) (inclusion of mandatory payroll deductions in the work expense disregard limits the work incentive for New York AFDC recipients).

115 Turner v. Prod, 707 F.2d 1109, 1123 (9th Cir. 1983), cert. granted sub nom. Heckler

v. Turner, 104 S. Ct. 1412 (1984).

${ }^{116}$ [L]ow marginal tax rates, from zero to, say, 15 or 20 percent, seem to have a relatively minimal effect on work effort; . . . as tax rates move up into the region of 40,50 , or even 60 percent, an increasing number of people are adversely affected; . . a as tax rates approach the confiscatory levels of 80,90 , or even 100 percent and more, the work disincentive becomes very powerful.

Id. at 137. 
to become self-sufficient ${ }^{117}$ and with the specific provision for work incentives in section 402 (a)(8) ${ }^{118}$ Moreover, to the extent that including mandatory payroll deductions in the work expense disregard discourages AFDC recipients from taking steps to become self-sufficient, it is inconsistent with OBRA's goal of reducing welfare spending by the government. ${ }^{119}$

C. Effectuating the Purposes of Limiting the Work Expense Disregard

Excluding mandatory payroll deductions from the work expense disregard, unlike the HHS regulation mandating their inclusion, is consistent with basic aspects of the welfare system-the availability principle and the creation of work incentives. Excluding mandatory payroll deductions from the work expense disregard is also consistent with the congressional purposes for limiting the disregard to seventy-five dollars, namely, reduction of variation among the states in the work expense disregard, prevention of welfare abuse, and administrative convenience. ${ }^{120}$ The variance among state tax rates creates a circumstance in which inclusion of mandatory payroll deductions actually undermines the goal of state-to-state uniformity. ${ }^{121}$ Furthermore, mandatory payroll deductions do not provide opportunities for abuse by recipients or occasion great inconveniences for AFDC administrators since they are "paradigmatic examples of amounts that are not subject to being falsified and are not difficult for states to calculate." ${ }^{22}$ The net income standard is therefore consistent both with the basic policies of the AFDC program and with the purposes of the OBRA amendment to the work expense disregard.

\section{ConClusion}

It is important not to lose sight of the purposes of the AFDC program in the maze of statutes, court decisions, and regulations defining the rights of recipients. Justice Marshall once observed that in focusing on a particular provision of the AFDC program "in order to determine its role in the statutory scheme, something of

117 See 42 U.S.C. $\$ 601$ (1976).

218 See supra note 55 and accompanying text.

119 See Senate Report, supra note 2, at 3, reprinted in 1981 U.S. Code Cong. \& AD. News 396, 398.

${ }^{120}$ See supra text accompanying notes 67-69.

${ }^{122}$ RAM v. Blum, 564 F. Supp. 634, 647 (S.D.N.Y. 1983).

${ }^{122}$ RAM v. Blum, 533 F. Supp. 933, 946 (S.D.N.Y. 1982). 
the general flavor of the overall legislation is undoubtedly lost."123 That "flavor," according to Marshall, "is to assist needy families to maintain strong family bonds and to assist needy individuals to realize their potential as unique human beings by providing them with the basic necessities of life, along with incentives and training to encourage them to work to help themselves."124

Although the OBRA amendments reduced the work incentives built into the AFDC program, they were not intended to eliminate these incentives altogether. Construing the work expense disregard to apply to mandatory payroll deductions is based upon an obsolete regulation and is inconsistent with both the availability and work incentive policies of the Social Security Act. In order to encourage AFDC recipients to "work to help themselves," mandatory payroll deductions should be disregarded from income. They should be disregarded, however, not as part of the section 402(a)(8) work expense disregard, but because they are not available income under section 402(a)(7).

Amy Klobuchar

${ }^{123}$ Jefferson v. Hackney, 406 U.S. 535, 574 (1972) (Marshall, J., dissenting).

124 Id. 